\title{
Assessing the Implementation Process of Consulting Citizen Participation in Policy and Housing Delivery in South Africa
}

Henry J. Ssekibuule

\section{Abstract}

This article aims to assess the implementation process of consulting citizen participation and conflicts involved in housing delivery against the environment of the South African housing need and housing policy. In this way the study wants to clarify the relationship between housing policy and housing practice. The article is based on the legislations and policies designed to foster and promote public participation in South Africa. These include legislation at both the national and local government levels and a survey of planning departments measuring the types of public participation strategies used by local governments. The article's findings indicate that South African Municipalities need adopt a broader range of public participation techniques related to: voluntarism and public engagement, neighbourhood and strategic planning, and e-government. In contrast, the article's findings indicate that South African Municipalities are more likely to crumple if they do not promote public participation through mechanisms such as annual community meetings and referendums on public issues. The conclusion of the article offers recommendations for expanding the scope of public participation and developing strategies that maximize citizen input in community development activities in both the Provincial and local spheres of government. The survey was conducted to identify the scope of public participation techniques used by local governments and the Department of Housing in Tyutyu housing project located in the Buffalo city metropolitan municipality. It is an initiative which was started in the year 2000 with the aim of alleviating housing shortage in the area. Formerly, the area was made up of mud houses that were constructed by the former Ciskei government. Later on, shacks were added in the area. Originally, these structures were meant to form agricultural rural village settlements. One limitation of this methodology is that it does not gauge the effectiveness of the participation techniques used by local governments and the department of housing or the intensity of public engagement. However, the results from this study provide future researchers with a mechanism for focusing future analysis. The findings can assist in identifying new directions for enhancing public participation in South Africa and globally.

Keywords: Consultation, Citizen Participation, Housing Policy, South Africa 


\section{Introduction}

South Africa has one of the most progressive constitutions in the world (Buccus et al, 2008). It includes the municipal legislative framework that provides for community participation in decision-making at municipal level. However, in practice, citizens have had little experience of this, which is particularly relevant in context of severe poverty and failure by the state to provide basic services. The case study of the Tyutyu housing project demonstrates the challenges faced by the National Housing Department when working to influence central government policy on citizen participation, when it forcibly attempted to remove the community who initially were fifty-two families from their area of domicile, which is present day Bhisho, without the former Ciskei government consulting them.

Some NGOs like the centre for public participation (CPP) found it challenging, working to influence Ciskei central government policy on citizen participation. Public participation also explores the role and influence of international donors in promoting this agenda. The Tyutyu Village Secretary, Mrs. Mabindisa, gave a historical perspective of the Tyutyu problem and it is important to note that because of South Africa's turbulent past, the disenfranchised majority was deprived of basic human rights. Public participation on the housing issues was a right reserved for the white minority. Today, as a democratic state, the Constitution of the Republic of South Africa of, 1996 regards access to proper housing a basic right to be enjoyed by all South Africans.

To further, show how the former Ciskei government policy of resettling the communities without public participation created problems, the study attempts to present an alternative situation of what would have happened had the government followed a public participation option. Firstly, in the research problem the government had consulted the people before moving the community, the people might have opted for a location that is not close to the city of Bhisho; avoiding the current issue of granting Tyutyu township status. Secondly, since the original people, who were moved from Bhisho, claim to be unskilled, having only agriculture as major livelihood strategy; the government could have settled this community on an area with agricultural potential and not on a peri-urban area, if public participation had been undertaken. However, it is commendable that the current Eastern Cape government has engaged the community before granting township status although the community is against such a step. It is for this reason that the community is resisting the move to grant Tyutyu community township status regardless of the benefits attached to it. These include improved roads, garbage collection, water reticulation services and street lighting. Both in short run and long run, this is affecting new people who have come into Tyutyu Village, since some of these are employed as well as ready and able to pay the requisite rates necessary to bring the improved facilities mentioned above.

Historically, South Africa's housing process was characterised by the previously disadvantaged being deprived of housing and property rights leading to rental and service boycotts by communities, thus challenging the legitimacy of the government of the day (Khan and Ambert, 2003: 4). The current housing policy is rooted in the pre-1994 
era as the policy was framed "in the course of National Housing Forum negotiations to address what (some influential) stakeholders saw as the threat of 'uncontrolled' urbanisation and the 'perilous politicization' of housing question" (Khan \& Ambert, 2003:4). The emphasis on housing delivery is compounded by the fact that the country's housing shortage was at estimated at 2, 2 million in 1997 by the National Housing Department. Due to an ever-increasing population, this figure is estimated to increase by 204000 every year (NHC, 2000b).

The housing shortage is the result of the apartheid regime which allocated the provision of housing along racial and class lines. This has resulted in a large proportion of South Africans living in informal settlements or receiving inadequate housing, exacerbated by unhealthy living conditions. Many of the problems created by this system still persist today. To address the above-mentioned problems, Developmental Local Government is mandated to provide the "creation of liveable integrated cities, towns and rural areas" (Housing Act, 1997a). As housing is a fundamental right of every citizen, it is government's responsibility to take reasonable measures to progressively realise this right (NHC, 2000b). Because of the recognised housing crisis, the Development Facilitation Act 67 of 1995 was formulated to introduce the measures and procedures to be used to speed up the implementation of development programmes relating to land and thus housing delivery.

The provision of housing is a developmental practice and development cannot prevail without public participation (Roodt, 2001:466). Apart from the Constitution of the Republic of South Africa of 1996, the (Housing Act, 1997a) is the cornerstone of any public housing initiative with regard to legislative requirements. Housing initiatives cannot be considered successful if not executed in compliance with the Housing Act of 1997. The emphasis on public participation opens a platform for each development initiative to take place in a different context. It is for this reason that the right combination of public participation strategies need to be used. Because each situation is different, "[e] effective, efficient and equitable stakeholder engagement depends largely on selecting the right combination of approaches and techniques for a particular process. There is, however, no single recipe for making this selection, particularly when operating in the context of a multi-cultural, developing country" (DEAT, 2002:14). For the purpose of this study, "stakeholder engagement" as used in the above-mentioned statement would be synonymous with "public participation."

\section{The Roads to Community Participation}

In the past three decades, support for community participation in processes of allocation of housing and housing delivery (referred to in this study as Citizen Participation in low income housing settlement) has risen among academics and development professionals. Because housing structures human interactions spatially, where people live plays an important role in determining with whom they interact and the quality of 
those interactions. Thus, houses are places created and used by people according to their behaviour patterns and living styles. In other words, it is defined as a social, psychological and emotional place, and is perceived as the tool for individuals to settle down, be family and sustain their existence across generations (Anonymous ( Erzen 2006:4). This support drives from three rationales:

- increased efficiency, to lower the cost of projects;

- increased effectiveness, to achieve a greater reach for housing among the poor; and

- empowerment of communities, to increase their influence in decisions that affect their living conditions.

These objectives of community participation can each be broadly located within one of two interpretations, which view participation of local communities in development projects either as a means (efficiency/effectiveness) or as an end (empowerment/emancipation) (Moser 1989:2).

The former view advocates mobilizing communities as a means to effective and efficient project implementation (see UNCHS 1984, 1985; Paul 1987:5). Critics point out that viewed in this way, community participation may indeed ameliorate communities' immediate problems but seldom then continues beyond the life of the specific projects and does not result in any greater community influence in decision making. Communities, especially women within them, become pools of cheap labour and do not challenge their larger political and economic contexts (Chambers 1998; Burkey 1996; Guijt and Shah 1998; Rahnema 1992:412). This interpretation of participatory processes is further criticized as satisfying the neoliberal rationale of efficiency and costeffectiveness at the cost of leaving communities to participate in other projects, without real influence in decision making or control over their life situations.

The latter view of community participation as an end stresses the empowerment derived from citizen consultation, as well, defining project goals and objectives and formulating policies. This perspective calls for the role of communities to change from that of passive recipients of projects' outcomes to active initiators of projects. Thus, ideally, the participatory processes build a sense of empowerment among participants by demonstrating that communities can change their lives and address their immediate needs through mobilization of their resources and reliance on their own power (Friedmann 1992:4). Often, however, these processes fall short of the ideal, and community mobilization may not achieve the participants' expected material gain. As empowerment, therefore, these processes are criticized for often leading to frustration in the communities insofar as the empowerment is bestowed inequitably.

It is for this reason that it is usually argued that in actuality the participatory arrangements fall prey to political abuse and replicate unjust development practices by benefiting the more powerful and more vocal, often men, within the community (Nelson \& Wright 1995; Guijt \& Shah 1998:6). 


\section{Conceptual and Contextual Issues}

This study looks at the various contexts of public participation. These are divided into international and local contexts of public participation. In the former, the chapter scrutinizes the various efforts, on a global scale, that have been made to promote public participation. On the South African context, the chapter briefly looks at the development efforts that have been initiated in South Africa and the extent to which it employed the public participation strategies. In addition, the chapter also inspects the legal context of public participation, which examines various legal instruments that have been crafted with public participation in mind. These also include various international agreements and treaties that have been signed to promote public participation between and within nation states.

To clearly understand the concept of public participation and how it interacts with the housing policy in South Africa it is important to cite several definitions that have been given to it by researchers. As defined by Greyling \& Manyaka (1999: 1) public participation is a "process leading to a joint effort by stakeholders, technical specialists, the authorities and the proponent who work together to produce better decisions than if they had acted independently" (in DEAT, 2002: 6). From this definition it can be realized that participation is seen as a decision-making process and aims to include the views of stakeholders at all levels of the process (Hoosen, undated: 2). However, According to Beinier, Public participation is engaging openly and respectfully in "give and take" discussions with citizens and/or stakeholders about an impending decision or action (Bernier, 2005: 2). COPR on the other hand defines public participation as the process by which an organization consults with interested or affected individuals, organizations, and government entities before making a decision. Public participation is therefore a two-way communication and collaborative problem solving with the goal of achieving better and more acceptable decisions (COPR, 2008: 1).

It is important to differentiate public participation from consultation. Looking firstly at consultation, it involves actively seeking the opinions of interested and affected groups. It is a two-way flow of information, which may occur at any stage of regulatory development, from problem identification to evaluation of existing regulation. It may be a one-stage process or, as it is increasingly the case, a continuing dialogue. Consultation is increasingly concerned with the objective of gathering information to facilitate the drafting of higher quality regulation. On the other hand, participation is the active involvement of interest groups in the formulation of regulatory objectives, policies and approaches, or in the drafting of regulatory texts.

Participation is usually meant to facilitate implementation and improve compliance, consensus, and political support. Governments are likely to offer stakeholders a role in regulatory development, implementation and/or enforcement in circumstances in which they wish to increase the sense of "ownership" of, or commitment to, the regulations beyond what is likely to be achieved via a purely consultative approach. However, there are instances where the two are inseparable. For instance public 
participation usually involves notification (to publicise the matter to be consulted on), consultation (a two-way flow of information and opinion exchange) as well as participation (involving interest groups in the drafting of policy or legislation).

Since the 1960s, the urban planning profession in South Africa has developed increasingly sophisticated techniques and theories regarding how and why to involve citizens in planning processes. Critics pilloried the effectiveness of citizen participation during the War on Poverty, suggesting a new theoretical approach to participation itself was needed (Ambert, 2004:5). Despite theoretical disagreements about the proper definition of and practice of participation, professional housing literature reflects a consensus, a variety of additional techniques, that can enhance the process and result in more effective and democratic plans. These debates suggest ways in which planners can craft strategies that take into account social divisions and inequality, and effectively incorporate Internet technology into existing processes (Oakley, 1991:7).

The experience of limited participation during urban renewal and the debate surrounding "maximum feasible participation" in the 1950s and 1960s in South Africa sparked an intense professional interest in the topic of public participation in planning. The political and social turmoil in South African cities and the contested nature of urban politics raised serious questions about how participation should be structured, and how power should be distributed more broadly in the city. Public participation processes are encapsulated within various legislative mandates, such as, the IDPs, the White Paper on Local Government (South Africa, 1998c) and the White Paper on Transforming Public Service Delivery (South Africa, 1997b). Public participation is critical to the success of sustainable development and therefore, South Africa should justifiably "promote public participation, including through measures that provide access to information regarding legislation, regulations, activities, policies and programmes" (United Nations, 2002:71).

To improve chances of sustainable development there is a need to shift from a topdown approach towards a bottom-up approach. The bottom-up approach promotes people-centred development. People-centred development focuses on people and enhances the capacity to influence the direction and implementation of the development process. Communities can only influence the development process through participation. International bodies such as the United Nations and the World Bank support the concept of community participation in development planning.

For the purposes of this research article, four statutory instruments are used to show the extent to which the state has tried to incorporate public participation within its legislative framework:

- The Municipal Finance Management Act, (Act 56 of 2003);

- The Municipal Systems Act (Act 32 of 2000);

- National Environmental Management Act (NEMA) in 1998;

- White Paper on Transforming Public Service Delivery, 1997.

The Public Finance Management Act (PFMA) was adopted by parliament in 1999. It is intended to positively impact on budget transparency and participation, providing 
financial controls and improved accountability. Requirements include regular reporting and the assignment of accountability by national and provincial departments. The PFMA is an important measure for public financial management in South Africa. The PFMA was one of the first pieces of legislation to demand monthly actual expenditure reports from departments to treasuries, and audited financial statements to the legislatures within seven months of the end of the fiscal year. It sought to bring state-owned enterprises under the transparent scrutiny and accountability not yet exercised by the legislature (South Africa, 2000:4).

The Municipal Finance Management Act, (Act 56 of 2003) is the only legislation prescribing the need for municipalities to consult all communities falling under their jurisdiction in the course of municipal planning and budgeting (South Africa, 2000:3a). While the above may be contained in legislation, the actual practice undermines effective consultation. In recent interviews conducted by NALEDI amongst 77 people in Durban (KwaZulu-Natal), only two people indicated that they participated in the city's budget processes (Thompson, 2009: 3). Most people indicated that they did not know anything about city budget processes. They indicated that the advertisements for the ward meetings to discuss the budget gave insufficient short notice. This means that the budget cycle of the municipality could not possibly be shared with the communities.

The Municipal Systems Act (Act 32 of 2000) contains sections dealing with local community participation in the development of Integrated Development Plans (South Africa, 2000). They guide the local municipality on how to ensure community participation, specifying processes, and timelines. While legislative provisions are progressive, the reality within many communities is different. The media used to alert communities about meetings are not generally accessible across municipalities, and the notice for such meetings is often too short. The period set aside for consultation with communities is often too short. The timing of these community meetings tends to marginalise large sections of the local community in cases where these are held during the day when employed people are at work. With the aim to secure stakeholder input to the development of a new environmental policy, this process resulted in the adoption of the National Environmental Management Act (NEMA) in 1998. As far as its procedural environmental rights are concerned, NEMA is considered one of the most modern and innovative environmental framework statutes in the world. On the national level, the South African government has introduced what is commonly known as the Batho Pele Principles, which are found in the white paper on transforming Public service Delivery (1997b) and epitomises the evolution of public participation in South Africa. Batho Pele means "people first."

Focusing on these principles the government has established the importance of the South African public and their valued input through participatory means and called "for a shift from inward looking, bureaucratic systems, processes and attitudes and a search for new ways of working which put the needs of the public first and is better, faster and more responsive to the citizen's needs" (White Paper on Transforming Public Service Delivery, 1997b). The "people first," bottom-up approach is derived from the recognition 
that the total dependence on professional to implement development initiatives is grossly inadequate and contributes to greater underdevelopment (Oakley, 1991:4).

Another problem with housing delivery is that far more housing subsidies are approved than are paid out. In terms of public participation, the Housing Act of 1997 states that inhabitants of communities, affected by land development, should actively participate in the process, which coincides directly with the IDPs of all municipalities (Oakley, 1991:16).

Unfortunately it has not occurred as intended as "participation is often interpreted to mean acquiescence and voluntary contribution of labour and resources by low-income 'beneficiaries' who have no real influence on a project's goals and design or in establishing the rules within which it must operate" (Hassen, 2003:126). Some basic developmental local government characteristics are mention below:

- Maximizing social development and economic growth;

- Integrating and coordinating;

- Democratizing development, empowering and redistributing; and

- Leading and learning;

In terms of the housing development and its participation component, integration and coordination are discussed below within the Integrated Development Plans (White Paper on Local Government, 1998c).

\section{Integrated Development Plans (IDPs)}

The White Paper on Local Government (1998:17) considers developmental local government as a local government committed to working with citizens and groups within the community to find sustainable ways to meet their social, economic and material needs, and eventually improve their quality of lives. The expectation of this is that municipalities should co-operate with community stakeholders to enhance democracy and participation in local issues of concern and ensure that their priorities and needs are involved in IDP and addressed and effectively met (Caesar \& Theron 1999: 61). This includes the establishment of cooperation between local government and other community stakeholders even though the tensions that exist between some stakeholders like the political parties, Traditional leaders are regretted as the latter is the primary stakeholder, especially in rural communities. In the main, the citizenry is caught up in the confusion of the paradox as they are at the receiving end of the operation of municipalities and in some cases of traditional leaders.

Traditional leaders are the custodians of culture in society. The institution of traditional leadership has served the African people over many years and in various forms. The relevance of the institution of traditional leadership currently depends to a large extent on how the institution serves its communities customarily, culturally and developmentally (KZNILGTL, 2005:6). 
Municipalities are expected to make sure that, within the framework of national policy and provincial guidelines, constituents within their jurisdictional areas have access to adequate housing. They set aside, plan and manage land for housing and development in line with the housing priorities identified in their IDPs because they initiate, plan, co-ordinate and facilitate appropriate housing development within their boundaries and aim to ensure safe and healthy living areas. (Provincial Budgets and Expenditure Review: (2001/02-2007/08: 68). Integration and coordination involves the responsibility of local government to align standard visions and goals for all municipalities.

The legislation mentioned above should all be aligned in such a manner that they work towards housing delivery in an interdisciplinary manner so as to optimise results within the ambit of public participation. Integrated development planning, performance management and overall cooperation between stakeholders have been identified as tools and approaches for Developmental Local Government (National Capacity Building Strategy for Local Government, 2003:6). In spite of the above-mentioned legislation, the desired results have not always been achieved. The progress which municipalities have made in terms of realising IDP goals has been minimal as it is estimated that $60 \%$ of municipalities are still not implementing performance management systems whereas only $75 \%$ of municipalities had completed their IDPs by June/July 2002. (South Africa, 1997). This is a reflection of the lack of capacity within local government and its municipalities as they have yet to consolidate their core systems and structures, which include performance management, IDPs and review of delivery mechanisms (National Capacity Building strategy for local government, 2003:6). Public participation within the IDP process can only be considered successful if everyone within a specific community has had the opportunity to have their interests or opinions heard. It does not necessarily mean the participation of everybody within the entire life cycle of development initiative.

The successes of IDP are dependent on a common understanding and interpretation of the concept of public participation as a point of departure. Once this understanding has been established, the public participation strategies can be decided upon within the legal framework phases as regards public participation. The South African government has come a long way in addressing past injustices and current legislation is proof of the desire to learn from failed past practices, but internal capacity needs attention as "it is crucial that the facilitative potential of local authorities be developed and exercised to full" (CSIR,2000:26).

\section{The Housing Policy Perception}

This housing policy framework was the product of extensive negotiations prior to the 1994 elections, and it remains the central component of the government's housing plan. In addition to subsidy provision, the housing programme offers security of domicile to 
South Africa's poor in the hopes of building property markets and equity among the poor. Housing development is premised on an incremental approach, whether through self-building by the occupants themselves or in association with future access to credit or other developer-driven building schemes. The majority of homes built through the capital subsidy have been developer driven, although the Department of Housing has recently recognised the importance of small-scale savings associations and self-building groups comprised primarily of women-headed households.

Consistent with international experience in this regard, it was hoped that South Africa's poor would be both beneficiaries as well as active participants in the building process. The result would be sustainable and active communities in place of the often fractured and disempowered settlements generated by apartheid policies. But while the national government has been vocally supportive of this approach, its financial and administrative support in this regard has been relatively minimal. The scale of poverty (and recalcitrant lending from the formal mortgage sector) in South Africa has meant that the majority of homeless people or residents of informal settlements continue to lack the capacity to meet minimum basic needs. At the launch of the ANC's housing policy, the minimum subsistence income was calculated to be R970 per month. The example shows the monthly income distribution in South Africa in 1995. Rising unemployment and a growing income gap has exacerbated these inequalities. For example, the 2001 Census indicated a national unemployment rate of 33 per cent, with more than 40 per cent economically inactive (Statistics South Africa 2003:51).

Thus, in 1995, as the housing programme was being launched, nearly seven million households qualified for some form of housing assistance. Against this background of relative poverty, the government set the goal of building one million homes in the first five years of government, with housing expenditure promised to rise to 5 per cent of the national budget and a model of 'people-driven' development challenging the hold of the banks and private-sector developers. This absolute goal of building one million homes was met by 2000 , although the backlog in housing (estimated at three million homes) continues to grow.

In practice, both the policy and the process have been more complex than this brief policy summary. But several general points of debate emerge. Firstly, the goal of one million houses proved elusive prior to the 1999 elections but remains an impressive achievement in quantitative terms. Secondly, housing expenditure has not reached its target; and thirdly, developers rather than communities drive much of the housing process while the recalcitrance of the formal housing finance sector has frustrated ANC attempts to entice and leverage its participation. Fourthly, the quality and location of the houses that have been constructed have been criticised as inadequate, and in some instances have been compared unfavourably to the houses built under apartheid regime.

An example of the above situation is that of the Duncan village in East London, where the Buffalo City Municipality is currently involved in a planning initiative aimed at housing the residents of Duncan Village. Much debate exists over the appropriate methods to use in redeveloping this densely populated shack town. Planners are striving 
to meet the challenges associated with this kind of community redevelopment, such as adequate housing, limited land availability, appropriate urban forms, and government requirements for housing subsidies. However, despite the thoughtfulness of development policies and an increased awareness of local circumstances in Duncan Village, the Buffalo City Municipality has still not been able to implement an effective system of participatory planning (Kay, 2006: 512). As a result, housing and development strategies are still not effectively reaching community based organizations, families and individuals; and local residents are still not empowered to effect substantial change in their community. This is largely due to a strong desire by the local government to maintain a coherent master plan, a culture of civil resistance within Duncan Village, and an untested local political system.

In response to the challenges planners have encountered when trying to implement redevelopment plans for the shantytowns of South Africa, anthropologist Steven Robins mentions that "although there are no clear and obvious answers to these questions, it is only through further fine-grained ethnographic research in specific sites that planners will get closer to understanding the micro-politics and improvisational strategies" of those who live in these shanty towns (Robins, 2002:1). As the forced removals of Duncan Village were planned at the same time as the construction of the Mdantsane Township, the government was unable to remove the entire population of Duncan Village at once because sufficient housing had not been constructed in the new township. In the meantime, African resistance to forced removals grew in intensity throughout the 1960's and 70's and eventually disrupted the government's attempt to relocate residents to Mdantsane (Kay, 2006:511).

The same problem with implementing projects without proper and extensive public participation can be found in the Coega IDZ project just outside Port Elizabeth where, at first glance, quite comprehensive and detailed public participation processes seem to have been conducted (Bond, 1999: 1). However, this is doubtful if one considers the history of the project which is vexed in controversy and public dispute which is threatening to all but stall it (Burger \& Bradshaw, 2002: 2). The proposed Coega development is popularly presented as of great necessity in the South African and Eastern Cape context, but at the same time may have far reaching implications for the region, environment and community surrounding it.

Since the idea was firstly raised, the proposed project evoked much conflict and controversy because of the absence of consultation with communities who would be in any way affected by the project (Bond, 1999: 3). It is not only the validity of the public participation processes conducted in connection with the project that was questioned. Other processes questioned include the project's economic viability, its environmental impact and the public accountability of the concerned development agency (the Coega Development Corporation). Also important is the uncertainty surrounding the commitment of possible foreign investors tied to the IDZ through the arms procurement deal. All this controversy and public disputing have cast serious doubt upon the public participation processes conducted in connection with this project, and it is the aim of 
this article to try and find some answers for why that may be the case (Burger \& Bradshaw, 2002: 4).

\section{Statement of Research Problem}

South Africa has one of the most progressive constitutions in the world. It includes the municipal legislative framework that provides for community participation in decisionmaking at municipal level. However, in practice citizens have had little experience of this, which is particularly relevant in contexts of severe poverty and failure by the state to provide basic services (Buccus et al, 2008).

This case study of Tyutyu problem, demonstrates the challenges faced when first, the community who initially were fifty-two families (52) was forcibly removed from their area of domicile, which is present day Bhisho without the former Ciskei government undertaking some public participation steps to get the views and eventual concurrence of the Tyutyu community. Secondly, again the government did not engage the community in public participation when it went on to resettle them at a place, which apparently the community did not approve of. Thirdly, public participation was again disregarded when the government built houses for the community in 1985 leading to the current problem where the Eastern Cape government is making efforts to turn Tyutyu village into a township.

The Tyutyu Village Secretary Ms. Nandipha gave a historical perspective of the Tyutyu problem and it is important to note that because of South Africa's turbulent past, the disenfranchised majority was deprived of many basic human rights. Public participation in housing issues was a right reserved for the white minority. Today, as a democratic state, the Constitution of the Republic of South Africa, 1996, which is the supreme and sovereign law of the country, considers access to proper housing a basic right to be enjoyed by all South Africans.

\section{The Methodology}

The article is based on the methodological principle used in gathering the data; secondly, provides a brief overview of the Tyutyu housing project into informal settlement; and thirdly, examines the significance of those families, who were forcibly removed from Bisho location in 2000 to Tyutyu housing project informal settlement. It describes and justifies the methods and processes that were used in order to collect data employed in answering the research questions.

\section{Research Design}

The research design seeks to assess public participation mechanisms of local municipalities when they design their Integrated Development Plans (IDP), especially when it comes to the housing policy. In this case firstly, the research seeks to appraise the current strength and weaknesses of the public participation strategies in its housing 
policy. Secondly, the research also aims to make an objective contribution to the improvement of the general housing delivery policy strategies in South Africa.

\section{Sampling and Data Collection}

The study presented used a total sample of a target population of 5200 as of the last census of 1999 (Buffalo City IDP: 2002) the target population is made up of the 373 project beneficiaries. (Buffalo City: 2009). Other Tyutyu community members were also included to determine the extent in which the community was involved in the formulation and implementation of the project. The participants were selected by a stratified random sampling and survey techniques were used in gathering the research materials to pick up the project beneficiaries. Data were collected between AugustSeptember 2010.

\section{Data Collection Instruments}

Data was collected through interviews and questionnaires. Two questionnaires were used. The first one was for the original project beneficiaries who moved there in 1985. The second was for project beneficiaries who came later on in Tyutyu. In both instances, both open ended and closed ended questionnaires were employed. These questionnaires were distributed by the Community Development Worker (CDW) who also collected them after the exercise.

Face to face interviews were employed primarily for other public officials; NGO personnel as well as various stakeholders who worked on the project were interviewed. Group interviews were also employed to get the collective opinion of the project beneficiaries. The data collection took a minimum of one month.

\section{Data Analysis and Interpretation}

The collected data was coded and collated to make the data analysis manageable. During analysis, both quantitative and qualitative analysis was used. To ensure that the research results are accurately captured and analysed, several computer applications were used for data analysis. These packages include Microsoft Excel and Statistical Presentation for Social Sciences (SPSS). This research will draw mainly on qualitative methodological tools as these are deemed most appropriate to gathering information in order to answer the research question.

\section{Semi-structured interviews}

Semi-structured interviews were conducted with local government officials, community representatives and beneficiaries of the housing process in order to gather information 
relating to existing structures, the respective roles of the different stakeholders, and the nature and extent of community participation.

Eight interviews were held with officials, including two representatives from the Buffalo City Municipality King Williams Town' housing department; one housing project manager; three local government officials dealing directly with the Tyutyu housing Project; and two Ward Committee members responsible for the case study area.

Semi-structured interviews were also held with 10 representatives from community organisations in Tyutyu Village. Discussions were firstly held with two representatives from $\mathrm{CBO}$, a non-profit organisation in the case study area whose primary aim is the upgrading of Tyutyu Village. Three representatives from the Community Organisation Resource Centre (CORC), which includes professionals and grassroots activists providing support to poor communities, were also be targeted.

\section{Observation}

The researcher attended community meetings in order to determine the extent to which community members are involved in decision-making processes; assess the level of participation of community members, and to determine the different roles that community members play in meetings. Furthermore, the meetings were observed in order to evaluate whether the meeting setting and/or power structures encourage or inhibit participation.

\section{General findings}

During fieldwork, an overwhelming majority of the respondents, amounting to $94 \%$ of the respondents said they did not see the newspaper adverts and inserts which were placed in the local newspapers by the government regarding the introduction of the Tyutyu Housing project (Ssekibuule, 2011). This can be interpreted as a failure by the government to choose the proper participation strategy as most of the intended beneficiaries have low education levels and basic of their socio-economic status, are least likely to buy or even read newspapers. After the commencement of the project, all the respondents noted that they were aware of meetings and briefings which took place concerning the project. However, while the people were aware of the meetings and briefings, their attendances were irregular, with only $3 \%$ of the respondents saying they attended all the meetings and briefings (Ssekibuule, 2011). The reason which was given for the failure to attend the meetings regularly is the fact that almost invariably the meetings are called at short notice giving little time for the respondents to attend. It seems during the meetings, the items which were most dominant were the policies, selection of project steering committee and employment opportunities for the communities.

Nevertheless, as pointed earlier, all the respondents complained that most of the meetings are called at short notice rendering them rather ineffective as they are not 
given enough time to prepare and attend. The other cross-cutting which was also pointed out by the respondents is that once elected, the steering committee members become almost invisible and are only apparent when the next elections are held. The same sentiments were also expressed for the councillors, whom the respondents looked up to as their link with the government and other stakeholders likely to improve service delivery in the village.

During the survey it was observed that most of the respondents reported that they were not involved or consulted in the actual process leading to the formation of the Tyutyu village (Ssekibuule, 2011). This even came out in the response to the semistructured question which was posed to the Tyutyu community members. However, it seems from the responses that they were only consulted in a limited way on the actual structures that were going to be build and the eventual structures did not represent the expectations of the occupants hence their unanimous response that they are very dissatisfied with the houses in which they are living now. From the respondents, it seems most of them were only involved in the pre-construction stage where they were asked on the size of house they wanted.

The other general observation from the survey is the oxymoron in what the government should do to alleviate the situation and the practicalities on the ground. For example, considering the relatively small size of the houses and the disproportionately large families, it is almost apparent that the government should build houses for the community members. This can also include making available several amenities like access roads to the village. However, there are service costs attendant with these services. Considering the relatively small and limited incomes of the sampled respondents, it's unlikely that they will be able to afford the cost which comes with the services that they want.

During this research, it was found that municipalities play a critical role in development because they are simply closer to local communities. They are legislatively obliged to foster participatory democracy and encourage the participation of beneficiaries in all development initiatives. The process is intended to be transparent, empowering and inclusive, and local government must be responsive to community input and be held accountable for their decisions.

However, in the case of Tyutyu housing project, research findings indicate that citizen consultation, participation and community engagement in housing allocation and delivery do not essentially result in effective outcomes. Empirical fieldwork in the community revealed that there are many reasons for the lack of effective participation and the inclusion of the voice of the people in development outcomes. These reasons are as follows:

- Citizen consultation, participation, and involvement, can sometimes be time consuming and become a tedious process, especially if there are disagreements on a particular issue.

- Government officials and politicians/representatives at times impose their ideas in community meetings to make their job easy and fast. 
- In some cases, community representatives do not participate in the IDP formulation process.

- Even if they do participate, there is a general feeling that their concerns are not taken into account since they are considered ignorant of the subject matter.

This research project also came to the conclusion that political affiliations and gatekeeping are critical impediments to meaningful community engagement. This is because people who belong to the same political party as community representatives receive valuable information while other members of the community do not.

Community structures, in particular the Tyutyu Village Task Team, play a critical role in ensuring citizen consultation, participation and community engagement. The Tyutyu Village Community is eager and prepared to give solutions to their developmental problems if the projects are to be sustainable.

Even though community meetings have such a high value, there are some limitations identified. Both general and special meetings are not conducted frequently. Some critical community issues are removed from the agenda because some community members are more influential and do not consider other issues important.

Throughout this research project, it was shown that the community closely associates meaningful community participation with democracy and that community engagement by government is critical for strengthening democracy and the construction of good governance.

Housing provision and citizen consultation, community participation in the process is a legal requirement in South Africa. The Constitution, Housing White Paper, Housing Act, BNG and the Housing Code oblige local government to work with their respective communities in housing delivery. The Tyutyu Village community can use the IDP process to communicate their needs. Within this process, the Councillor and the Ward Committee play a critical role in channelling information back and forth. It can there be deduced that an effective Councillor will lead to meaningful citizen consultation and community participation. In the context of Tyutyu housing Project, the Councillor does not allow the community to participate in the IDP process of the Buffalo City Metropolitan Municipality (BCMM) because of the lack of communication.

A reasonable time should have been given to officials to interpret the policies, plan properly and implement accordingly. The lack of capacity on the side of the officials has impacted negatively on development projects; therefore, enough time should have been allocated to human resource development which would in turn have taken care of the economic development of this country.

\section{Impact of participation at Local and provincial level}

Local government should be exceptionally participatory, fundamentally by the fact that they are closer to the Tyutyu Village community than any other sphere of government. The close proximity of local government to the Tyutyu Village community also means that citizen consultation, transparency and accountability take place. Local government 
is placed in a favourable position to work closely with the Tyutyu community. The local government and the Joe Slovo community can take advantage of this platform to enhance the South African democracy.

If citizen consultation, participation, involvement, community engagement does not happen; local people do not take ownership of development initiatives. Local communities would resort to violent demonstrations, as was evidenced in Tyutyu housing Project when they felt that their relocation was not properly communicated to them. The legitimacy of local leadership, such as the Councillor, would be questioned. This illegitimacy of local leaders would result in the community undermining the developmental role that the Councillor plays. The social structure and community trust can be affected as there is unfair treatment of the citizen and community. It can be concluded that participation at a local level is important for sustainable housing delivery in Tyutyu Village Community.

An understanding of the extent of participation by different stakeholders seemed to be a predicament as government structures such as the Ward Councillor and the Ward Committee pay lip service to participation. Furthermore, the Ward Councillor and the Ward Committee only engage people who are within their political party, which leads to gatekeeping tendencies.

It was also realised that the opportunities for participation are to a large extent limited in the Tyutyu Village community. In community meetings, people have a platform to raise burning issues concerning housing delivery and other community issues. Most people feel that meetings are important because their leadership gets to listen to their grievances.

The analysis shows that government in its implementation of the Tyutyu housing project did not follow the then statutory instruments on public participation in its housing policy. Furthermore, the delay by the Government to deliver on its mandate and allow the community members to have access to decent houses has led the Tyutyu community members to resist the idea of Tyutyu being given township status and all the benefits that come with such status like improved roads, garbage collection and water reticulation services and street lighting.

\section{Conclusion}

According to the study, indications are that the department under study did not involve the beneficiaries. Even the consultation was predominantly top to bottom. It was mainly the authorities who were consulted and had to pass the information on to the lower ranks. This highly caused a great inconvenience for those beneficiaries who had expected a social development in the area but had to suffer because of improper management from the government's side.

The legislations which govern housing delivery are adequate in terms of making provision for all developmental aspects but the government officials are seemingly not 
implementing these policies correctly to produce what they are meant for. Most of the delays in housing projects manifest a lack of capacity on the side of the officials. On the side of the officials performance management system seems to be unrealistic and unjust. Officials' capability and performance should thus be properly assessed to identify gaps which would assist government in developing relevant capacity building models to enhance the knowledge and skills for the benefit of service delivery.

\section{Recommendations}

The Constitution of the Republic of South Africa, 1996 requires that the municipalities should ensure that the machinery of government, especially local government, discharges its responsibilities effectively and efficiently, honouring the precepts of the Batho Pele principles. The Local government elections are an important milestone for South Africans. They provide an excellent opportunity for the newly elected councillors to fulfil their mandate to the best of their abilities and to deliver quality services and promote development to improve the lives of all South Africans.

Considering the constitutional requirements and legislation relating to the provision of housing and basic needs like electricity, clean water and sanitation, decent houses, access to roads and infrastructure, it appears that the government has not fully accomplished its objectives. This is a huge challenge. There are many factors that affect service delivery, particularly at local levels of governance, like the lack of capacity to monitor and evaluate service delivery. The management of local municipalities should play a leading role in making sure that proper planning, procurement process, commitment, monitoring and control measures are put in place. The tensions between the elected politicians and appointed administrators or officials should be wellmanaged, because they have a negative impact on service delivery.

Local Government and Housing Department should establish a task team comprising of officials from the Project Management, Monitoring and Evaluation and Customer Care Services divisions and the Municipality to develop effective remedial action for contractors. The established task team should have clear terms of reference on taking short term measures for repairs for damaged houses, completion of houses and issuing of title deeds. The team should do audits for both poor quality houses and those which need to be completed. The audits will help to verify the beneficiaries' existence and legitimacy as some of the beneficiaries' status has changed because most of the incomplete structures have been abandoned for many years.

The Department should also set a cut-off date for all faults that had been made in order to maintain control and manage the change which will be brought by the newly adopted processes. Bester field (2010:131) states that "the strategy is simple;" anything broken must be fixed so that it functions as designed. The two levels of this strategy are that if a housing beneficiary receives a house which has flaws such as a roof that keeps on being blown off by the wind and collapses; a quick fix is required as a temporary short-term measure. Although a short-term measure can solve the problem, it should not be permanent. The secondly level should occur when an individual or a team 
identifies and eliminates the root cause(s) of the problem, and effects a permanent solution.

Both the Department and the contractors should see to it that there is good project planning to avoid abandoned housing projects. The officials should always conduct inspections and continuous Monitoring and Evaluation to ensure that the contractors are complying with the specifications according to the contract entered into with the Department. The Department has to have legal grounds to hold contractors responsible for the above-mentioned. If contracts are legally sound, contractors who abandon the projects and those who build poor quality houses should have to be summoned to fulfil their contractual obligations.

In order to achieve this, the local municipalities must make sure that all the stakeholders are part and parcel of service delivery. Housing development should now focus on the areas that were neglected in the past, particularly the rural areas where most people are poor and vulnerable. Gaps have arisen between the introduction of new policy measures, legislation, guidelines and procedures and their application, including a lack of institutional coherence around key aspects, such as the introduction of beneficiaries' contributions. In some instances severe disruptions have been caused by policy shifts and the uneven application of policy. It has been acknowledged that the introduction of policy changes or amendments may cause slow-downs in delivery as the changes are implemented and systems developed. The subsequent alignment resulting from revisions to housing policy and legislation may lead to uneven expenditure patterns.

Corruption and financial maladministration can result in a very negative perception of councillors and municipalities. All the structures of local municipalities, the political arm, the administration and other levels of government need to conduct the financial activities of the municipalities in a professional, open, transparent and accountable way for the smooth running of all the activities and programmes of local municipalities.

\section{List of References}

- Arnstein, S.R. 1971. A Ladder of Citizen Participation. Journal of the American Institute of Planning. 35(4), pp. 216-224.

- Bester field, D.H., C, M. 2003. Total Quality Management. 3rd ed. Pearson.

- Bond, P. 1999. Economic Growth, Ecological Modernisation or Environmental Justice? Conflicting Discourses in South Africa Today, Paper presented at the Union of Radical Political Economics conference "Political Economy, the Environment and Economic Crisis," Bantam, Connecticut. 
- Brody, S.D., Godschalk, D.R., Burby R.J. 2003. Mandating Citizen Participation in Plan Making: Six Strategic Planning Choices, Journal of the American Planning Association, 69(3), pp. 245-264.

- Burger, W. \& Bradshaw, G. 2002. Public Participation in the Development Of The Coega IDZ: A Flawed Process?, A joint paper presented to the International Conference on Defence Offsets and Economic Development, Cape Town.

- Burkey, S. 1993. People Firstly. A guide to self-reliant, participatory rural development.

- Caesar, N. and Theron, F. 1999. Assessing attitudes and perceptions on Integrated Development Planning. The Case Study of Stellenbosch. Administratio Publica, 9 (2).

- Carrim, Y. 2001. Bridging the gap between the ideas and practice: challenges of the New Local Government System. Umrabulo, No.10. May. Marshalltown.

- Chambers, R. 1994. "Participatory rural appraisal (PRA): Challenges, potentials and paradigm," World Development, 22(10), pp. 1437-1454).

- Cooke, B \& Kothari U. 2001 Participation: The New Tyranny? (London: Zed Books)

- COPR, 2008. Role of the Public in Research work Group, Presented to NIH Director, October $31,2008$.

- Creighton, J.L. 2005. The Public Participation Handbook: Making Better Decisions through Citizen Involvement, (San Francisco, Jossey-Bass).

- CSIR, 2000. Housing is not about Houses: The BOUTEK experience. (Pretoria: CSIR Division of Construction Technology)Education Ltd.

- Gergis, A. 1999. Citizen economic empowerment in Botswana: Concepts and principles

- Goodspeed, R.C. 2008 Citizen Participation and the Internet in Urban Planning, Degree of Master of Community Planning Thesis, University of Maryland, Government Printers.

- Greyling \& Manyaka, (1999) Public Participation RHP Implementation Manual, National Aquatic Ecosystem Bio monitoring Programme Hall, Inc. Simon \& Schuster Company.

- Hassen, E. 2003. When more means less: low income housing and macroeconomic policy in South Africa. In Khan, F. and Thring, P. (ed) Housing policy and practice in post apartheid South Africa (Sandown, Heinemann).

- Kay, D. 2006. Development Planning and Public Participation in Slum Settlements: Improving participatory planning in Duncan Village, South Africa, MA Dissertation, Brigham Young University.

- Khan, F. \& Ambert, C. (2003) Preface in Khan, F. \& Thring, P (ed) Housing policy and practice in post-apartheid South Africa (Sandown, Heinemann).

\section{AUTHOR'S CONTACT:}

\section{SSEKIBUULE, Henry J.}

